\title{
FBI unveils \$48 million project for tracking criminal DNA
}

US criminals will be facing more DNA evidence in the courtroom as the result of US president Bill Clinton's recent signing of the "Crime Bill." A little known provision in the antiterrorism section sets aside $\$ 40$ million over the next five years to institute a sophisticated database of DNA samples taken from convicted criminals. The funds will be added to an earlier allotment of $\$ 8$ million to the US Federal Bureau of Investigation (FBI, Washington, DC) passed by Congress earlier this year. "We had no idea this project was going to be funded at this level until after the bill was signed," said an overjoyed Jay Miller (FBI), director of the project, at a recent conference on Forensic Diagnostics in Santa Fe, NM [April 21-26, 1996, sponsored by Cambridge Symposia (Newton Upper Falls, MA)].

The system, called CODIS for Combined DNA Index System, was launched back in 1991 by the FBI as a pilot program to make DNA evidence available to police departments at a state and local level. But the system was hampered by its lack of a relational database, and overly rigid query options resulted in a slow, unreliable system that was rarely used successfully.

The new CODIS uses state-of-the-art servers connected through an internet-like routing system with a fully relational database and a versatile, user-friendly interface. "Queries that used to take an hour or more can now be done in less than a minute," says Paul Farrara (Virginia Division of Forensic Science, Richmond, VA), an enthusiastic supporter of CODIS. Miller says that, typically, the system will query 17,000 DNA profiles in less than a minute. The US government funds will go toward instituting the system in local police departments in those 41 states that have passed legislation requiring convicted offenders to submit DNA samples. The FBI will provide software, training, and support free of charge, as well as maintain the database and the routing system. In so doing, the FBI hopes to standardize DNA collection and testing so that if DNA is found at a crime scene the local police department can run a quick search to determine if it is a probable match to a known criminal. The network is projected to be up and running in July 1996.

CODIS is not the only DNA-profile database that is operating currently. In the UK, the Forensic Science Service's (FSS, Birmingham, UK) National DNA Database has been running since April 1, 1995. One problem with the FSS system has been the backlog of samples waiting for entry into the database; a couple of months ago, as many as 60,000 samples were awaiting input. The backlog is being addressed by the FSS and, according to Paul Debenham at University Diagnostics (London), "entries are now being lodged on the database at a rate approaching 10,000 profiles per month." Elsewhere in Europe, progress is slower. Peter Martin, secretary of the European DNA profiling group (EDNAP), says that legislation to establish national DNA databases is currently being debated in Norway, Sweden, and Denmark. "No other European country has imminent plans for establishing a DNA database...," he added.

In the post-O.J. Simpson trial world, how effective is DNA evidence going to be in convincing juries to convict (see "NAS calls DNA forensics very robust")? The almost unanimous opinion at the Santa Fe conference was that DNA evidence is becoming stronger rather than weaker in persuading juries of innocence or guilt. "We are beginning to see juries that ask us why the prosecution didn't present any DNA evidence in cases where blood evidence is involved," says George Clark (Office of the District Attor- ney, San Diego, CA), who worked on the Simpson case. His adversary in the case, Peter Neufeld (National Association of Criminal Defense Lawyers, New York) agrees that this type of evidence is becoming increasingly important in the courtroom. "At our Innocence Project (Cardozo Law School, New York), over the past five years we've been able to free 36 inmates on death row through the strength of DNA evidence," says Neufeld. "From what we've seen so far, we estimate that at least $10 \%$ of the present prison population might be exonerated through this type of evidence."

Given the growing power of DNA to convict or exonerate, the FBI's CODIS system, once fully deployed, should be a significant boon to criminal justice: Not only will it be more difficult to evade justice, but for those wrongly incarcerated, DNA evidence may become the new "higher authority" for legal appeal.

\section{Stephen M. Edgington
Additional reporting by Andrew Marshall}

\section{NAS calls DNA forensics very robust}

DNA forensics have "come of age," says a committee of the US National Academy of Sciences (NAS, Washington, DC) in their report "The Evaluation of Forensic DNA Evidence," completed in early May. When samples containing DNA are "properly collected and analyzed," improved technology, accumulated human population genetics data, and better methods for handling statistical analysis remove much of the doubt from conclusions about matchups between DNA from suspects and crime-scene specimens or other evidence. However, according to the report, the problem of conveying these conclusions clearly to lawyers and jurors still needs to be addressed.

As NAS committee chair, James Crow, a geneticist from the University of Wisconsin (Madison, WI) points out, the question of whether any two people other than identical twins can have matching DNA profiles has proved a stumbling block in the courtroom. DNA profiling has proved particularly vulnerable when lawyers and expert witnesses have raised the possibility of profile overlaps for individuals of the same race or similar ethnic backgrounds. However, with "a greater abundance and variety of population data," Crow says there can now be "greater certainty" about the conclusions drawn from DNA evidence.
The NAS report concludes that, although it makes sense to choose a database for a "relevant" population group, outcomes from DNA forensic analysis are not likely to vary by more than about tenfold when the overall probability of an incorrect matchup is something like 1 in 20 billion. In an earlier report published in 1992, the NAS recommended applying a "ceiling principle" in order to establish upper limits for false matchups when making such estimates. Crow now says that this "interim" measure is "no longer necessary" in the light of experience, accumulated data, and alternative statistical analysis.

Nevertheless, the report recognizes that DNA evidence can be confusing and may be manipulated. It recommends that behavioral researchers find better ways to convey information about DNA in courtrooms. "This report offers guidance and provides reasonable figures to help jurors assess DNA evidence," says committee member David Kaye, professor of law at Arizona State University (Tempe, AZ). Still, he says, although lawyers and jurors may be among the "last links" in the chain along which DNA evidence passes, they are "not necessarily the weakest" when the time comes to base conclusions on it.

Jeffrey L. Fox 